\title{
IN VITRO DEVELOPMENT OF PORCINE NUCLEAR-TRANSFERRED EMBRYOS DERIVED FROM FIBROBLAST CELLS ANALYSED CYTOMETRICALLY FOR APOPTOSIS INCIDENCE AND ACCURACY OF CELL CYCLE SYNCHRONIZATION AT THE G0/G1 STAGES*
}

\author{
Marcin Samiec*, Maria Skrzyszowska, Michał Bochenek \\ Department of Biotechnology of Animal Reproduction, \\ National Research Institute of Animal Production, \\ 32-083 Balice n. Kraków, Poland \\ •Corresponding author: marcin.samiec@izoo.krakow.pl
}

\begin{abstract}
The study was undertaken to examine whether various strategies, including contact inhibition and serum starvation, that were used for artificial synchronization of mitotic cycle of porcine fibroblast cell lines affect differently the distribution of cell cycle stage frequencies and the occurrence of apoptotic cell death in the analysed cell samples. In vitro cultured (contact-inhibited or serumstarved) somatic cells were subjected to flow cytometric diagnostics of mitotic cycle together with the detection of late-apoptotic cell fractions with hypodiploid number of nuclear DNA molecules. Moreover, impact of the methods applied to synchronize the cell division cycle of different types of nuclear donor fibroblast cells (adult cutaneous and foetal fibroblasts) on the preimplantation developmental outcomes of cloned pig embryos was investigated. The developmental capabilities of nuclear-transferred (NT) embryos that were reconstituted with contact-inhibited or serum-depleted adult cutaneous fibroblast cells to reach the morula and blastocyst stages remained at the levels of $169 / 278(60.8 \%)$ and $76 / 278(27.3 \%)$ or $121 / 265(45.7 \%)$ and $46 / 265(17.4 \%)$, respectively. The proportions of NT embryos originating from contact-inhibited or serum-deprived foetal fibroblast cells that completed their development to the morula and blastocyst stages were $223 / 296(75.3 \%)$ and $108 / 296(36.5 \%)$ or $165 / 261(63.2 \%)$ and $67 / 261(25.7 \%)$, respectively. In conclusion, the flow cytometric analysis of cultured porcine adult cutaneous and foetal fibroblast cells revealed the high efficiency of the artificial synchronization of mitotic cycle at the G0/G1 stages as a consequence of applying the methods of either contact inhibition or serum deprivation. For both types of fibroblast cells used to reconstruct the enucleated oocytes, the strategies that were utilized to synchronize the cell division cycle of nuclear donor cells considerably influenced the in vitro developmental abilities of NT pig embryos. Developmental competencies to reach the morula/blastocyst stages for cloned embryos that had been reconstructed with contact-inhibited or serum-starved foetal fibroblast cell nuclei were significantly higher than those for embryos that had been reconstructed with contact-inhibited or serum-starved adult cutaneous fibroblast cell nuclei.
\end{abstract}

Key words: porcine, nuclear donor fibroblast cell, flow cytometry, mitotic cycle, cell cycle synchronization, apoptosis, DNA hypodiploidy, cloned embryo

In spite of tremendous improvement in somatic cell cloning efficiency of pigs (Harrison et al., 2004; Lee et al., 2005; Samiec and Skrzyszowska, 2011; Whitworth

*Source of research financing: This study was conducted as a part of both research project No. N R12 003606 and statutory activity No. 02-1.00.1, which were/are financed from 2009 to 2013 by the National Centre for Research and Development in Poland and from 2012 to 2014 by the Polish Ministry of Science and Higher Education, respectively. 
et al., 2011), high early-, mid- and late-gestation mortality rates of nuclear-transferred (NT) embryos/foetuses, cumulative occurrence of stillbirth, increased incidence rates of both sudden perinatal death and serious neonatal morbidity as well as numerous malformations (i.e., various congenital histo- and anatomopathological abnormalities) of cloned newborn offspring still often appear in this species (Archer et al., 2003; Kolber-Simonds et al., 2004; Koo et al., 2004; Park et al., 2004 a, b). The studies focused on pig cloning confirmed that pre- and postimplantation development of NT embryos/foetuses depends to a high degree on the preservation of appropriate requirements in all steps of somatic cell nuclear transfer technique (Yin et al., 2002; Kawakami et al., 2003; Kurome et al., 2003; Lee et al., 2003 a; Samiec, 2004). One of the most important factors that determine the effectiveness of somatic cell cloning are structure-functional quality of nuclear donor cells (Lee et al., 2003 b, c; Skrzyszowska et al., 2006; Samiec and Skrzyszowska, 2012 a, 2013; Samiec et al., 2013) and the extent of both nuclear-cytoplasmic and epigenomic maturity of recipient oocytes whose cell cycle has been transiently blocked at the metaphase II (MII) stage of meiosis (Hyun et al., 2003 a; Lee et al., 2003 b; Samiec and Skrzyszowska, 2012 b). Furthermore, the proper coordination between nuclear donor cell phenotype and cell cycle stage, methods of maternal chromosome elimination, techniques of enucleated oocyte reconstruction, procedures of reconstituted oocyte (clonal cybrid) activation as well as systems applied to in vitro culture of cloned embryos seem to be also crucial (Hyun et al., 2003 b; Im et al., 2004; Kurome et al., 2003; Lee et al., 2003 a, c, 2005; Skrzyszowska et al., 2008; Samiec and Skrzyszowska, 2005 a, 2010; Samiec et al., 2012). Transcriptional activity of donor nuclear and mitochondrial genomes during pre- and/or postimplantation development as well as foetogenesis of NT embryos is correlated with the frequency of remodelling/reprogramming for epigenetic modifications including DNA methylation/demethylation and histone deacetylation/acetylation (Santos and Dean, 2004; Samiec, 2005 a, b; Samiec and Skrzyszowska, 2005 b; Kumar et al., 2007; Kim et al., 2011; Whitworth et al., 2011).

The environmental stress factors imposed by physicochemical conditions of in vitro culture that affect to a high degree the cellular processes can be associated with different methods of inducible ectopic synchronization of the mitotic cycle of somatic cells at desirable phase/phases prior to their use for the cloning procedure. The methods frequently used to synchronize the mitotic cycle of in vitro cultured nuclear donor cells at G0/G1 stages, such as drastic serum deprivation (Kues et al., 2000, 2002; Anger et al., 2003; Hyun et al., 2003 a; Kurome et al., 2003; Lee et al., 2003 b; Park et al., 2010) or contact inhibition of their migration and proliferative growth after reaching a total confluence state (Lee et al., 2003 c; Im et al., 2004; Mohana Kumar et al., 2006, 2007; Park et al., 2010; Samiec and Skrzyszowska, $2012 \mathrm{a}, \mathrm{b})$, can contribute to a diminishment in the cellular viability to a large extent. These alterations in the rate of ex vivo somatic cell vitality may result from decline of both their metabolic and proliferative (karyokinetic and cytokinetic) activity, which can be caused by either physiological abnormalities in the intracellular processes specific for different organelles and compartments or gene mutations and chromosomal aberrations (Gómez et al., 2006; Mohana Kumar et al., 2007; Cheng 
et al., 2012). In turn, such complex changes mediated by slowing down/retarding or gradual inhibiting the cell division cycles can induce irreversible arrest of the mitotic cycle, as somatic cells pass through the G1/G0 phase boundary or reach the checkpoint linked with the transition of quiescent cells from G0 to G1 stage (Gómez et al., 2003; Hashem et al., 2007). Suppression of replicative and proliferative activity of artificially-synchronized nuclear donor cells can subsequently initiate their exiting the cell cycle, followed by entering the molecular scenario of apoptosis (Lee and Piedrahita, 2002; Molgat et al., 2009; Kulasekaran et al., 2009). Apoptosis or genetically programmed cell death is a physiological process responsible for normal development, differentiation and maintenance of cell/tissue homeostasis in multicellular organisms. However, inappropriately regulated apoptosis is implicated in several disease states, such as Alzheimer's disease and all the types of cancers. The apoptosis is induced by many factors that are varied both qualitatively and due to the manner of action on the somatic cell. The cell that dies through an apoptotic suicidal death exhibits a number of genetic, biochemical and morphological changes. These changes enable distinguishing the apoptotic cell from the viable, ultrastructurally normal or necrotic cell (Griffith et al., 1995; Kues et al., 2002; Sermeus et al., 2012; Todt et al., 2013). The process of active self-destruction of the somatic cell undergoing apoptosis involves well working suicide machinery, whose core component is a family of cysteinyl-dependent aspartate specific proteases known as caspases. These enzymes lie in a latent/inactive form of zymogens in the cells and become activated in response to a wide variety of cell death stimuli including also the group of ectopic (i.e., environmental) stress factors associated with the physicochemical conditions of in vitro synchronizing the cell cycle (Matthews et al., 2012; Yang et al., 2012; Kapoor et al., 2013). Moreover, a pivotal role in the functional regulation of all stages of apoptosis and in direct and/or indirect controlling the biocatalytic activity of many caspases is played by the protein products of expression of B-cell leukaemia/lymphoma ( $\mathrm{Bcl}$-2) protooncogene family (Molgat et al., 2009; Park et al., 2010; Sermeus et al., 2012).

Apoptosis is distinguished from necrosis, which is defined as an accidental or passive cell death, by a series of typical morhological and ultrastructural events, such as: 1) shrinkage of the cytoplasm; 2) chromatin compaction/condensation; 3) nuclear shrinkage and fragmentation, and 4) rapid phagocytosis of formed apoptotic bodies containing viable, non-degraded organelles by neighbouring cells. Active apoptotic cell death is characterized by both biophysical and biochemical changes in the lipid composition of the somatic cell plasma membranes, i.e., by the loss of their interlayer asymmetry/anisotropy in the ultratopology/distribution of phospholipid molecules through enzymatically-assisted translocation of phosphatidylserine moieties to the outer leaflet of the plasmalemma (Frasch et al., 2004; Skrzyszowska et al., 2006; Park et al., 2010; Samiec et al., 2013). During apoptosis the plasma membrane also becomes slightly permeant (Idziorek et al., 1995; Estaquier et al., 1996; Skrzyszowska et al., 2006; Samiec and Skrzyszowska, 2012 a, 2013). Furthermore, the apoptotic cells display alterations in the quantitative composition of nuclear DNA molecules (i.e., the so-called DNA hypodiploidy) triggered by the processes of internucleosomal chromatin 
biodegradation, which are detected by terminal deoxynucleotidyl transferasemediated dUTP (2'-deoxyuridine-5'-triphosphate) nick-end labelling (TUNEL) assay (Mohana Kumar et al., 2007; Cheng et al., 2012). Proteolytic cleavages of a set of key proteins by activated effector caspases play a role in the accomplishment of nuclear fragmentation. The main function of effector caspases is to catalyse the highly specific cleavage of various cellular proteins, whose biodestruction contributes to the biochemical and ultrastructural changes associated with apoptosis (Griffith et al., 1995; Sermeus et al., 2012; Kapoor et al., 2013). It has been shown that the chromatin degradation and nuclear fragmentation are two nuclear damages that are induced separately in the cells undergoing active suicidal death. The chromatin degradation is mediated by the activation of two apoptotic effectors, caspase- 3 and caspase-activated deoxyribonuclease (CAD). Disassembly of the nuclear lamina, the supporting structure of the nuclear envelope, is an essential feature of nuclear breakdown in apoptosis. A possible effector for lamina proteolysis and thereby nuclear fragmentation is caspase-6 (Matthews et al., 2012; Yang et al., 2012).

The majority of the methods of cytometric analysis are applied to detection of late molecular symptoms in somatic cells that take place during the final destruction phase of apoptosis. It is known that activation of endonucleases that preferentially cut genomic DNA at the internucleosomal sections is the characteristic phenomenon of late stages of apoptosis (Darzynkiewicz et al., 1992; Kapoor et al., 2013). Analysis of nuclear DNA (nDNA) content of in vitro cultured somatic cells undergoing apoptosis became one of the most common methods for single-parameter flow cytometric measurement of this process (Telford et al., 1992; Darzynkiewicz et al., 1994; Gómez et al., 2003, 2006; Hashem et al., 2007; Samiec et al., 2009 a, b). The frequency of apoptosis occurrence among the subpopulations of cultured cells subjected to artificial synchronization of their mitotic cycle is assessed by quantification of hypodiploid cells exhibiting nDNA oligonucleosomal fragmentation and subsequently the number of nDNA molecules that is lower than 2C DNA content. The cell fractions with hypodiploid $(<2 \mathrm{C})$ nDNA molecule number, which involve the so-called sub-G1/G0 spike or pre-G1/G0 peak (i.e., subdiploid region localised on the left of the G1/G0 spike) in DNA histograms/cytograms, are identified as lateapoptotic subpopulations (Darzynkiewicz et al., 1994; Samiec et al., 2009 b). Advantages of this method are both the precise estimation of apoptosis incidence in the analysed somatic cell lines and the possibility of simultaneous measurement of their cell cycle (Telford et al., 1992; Samiec et al., 2009 a).

The purpose of the present study was to examine the effect of two methods (i.e., contact inhibition and serum starvation) applied to cell cycle synchronization of adult cutaneous and foetal fibroblast cells at the G0/G1 phases on both its accuracy and in vitro developmental potential of porcine nuclear-transferred embryos.

\section{Material and methods}

\section{Collection and in vitro meiotic maturation of porcine oocytes}

Unless otherwise mentioned, all chemicals used in this study were purchased from Sigma-Aldrich Chemical Co. (St. Louis, MO, USA). 
Slaughterhouse ovaries were collected from both prepubertal female pigs (gilts) and postpubertal female pigs (gilts and sows). Cumulus-oocyte complexes (COCs) were recovered by aspiration of follicular fluid from 2- to 6-mm antral ovarian follicles using an 18-gauge needle attached to a 10-mL disposable syringe. The COCs were placed into HEPES-buffered Tissue Culture Medium 199 (TCM 199-HEPES; Gibco BRL, Life Technologies Inc., Grand Island, NY, USA) supplemented with 5 IU $\mathrm{mL}^{-1}$ heparin. The COCs, with evenly granulated ooplasm and several uniform layers of compact cumulus cells, were washed three times in TC 199-HEPES medium with addition of $4 \mathrm{mg} \mathrm{mL}^{-1}$ bovine serum albumin (fraction V; BSA-V) and selected for in vitro maturation under atmospheric conditions. Immature COCs were transferred into the wells of Nunclon four-well multidishes (Nunclon $\Delta$ Surface; Nunc A/S, Nalge Nunc International, Thermo Fisher Scientific, Roskilde, Denmark) filled with 500 $\mu \mathrm{L}$ of TC 199 maturation medium that had been overlaid with paraffin oil and equilibrated at $39^{\circ} \mathrm{C}$ in atmosphere of $5 \% \mathrm{CO}_{2}$ in air for 1 to $3 \mathrm{~h}$. The maturation medium was comprised of $25 \mathrm{mM}$ HEPES- and $26.2 \mathrm{mM}$ sodium bicarbonate-buffered Tissue Culture Medium 199 (Gibco BRL) supplemented with 10\% porcine follicular fluid (pFF), $0.6 \mathrm{mM} \mathrm{L}$-cysteine, $10 \mathrm{ng} \mathrm{mL}^{-1}$ recombinant human epidermal growth factor (rhEGF), $1 \mathrm{mM}$ dibutyryl cyclic adenosine monophosphate (db-cAMP; bucladesine) and $0.1 \mathrm{IU} \mathrm{mL} \mathrm{m}^{-1}$ human menopausal gonadotropin (hMG). Approximately 50 to $60 \mathrm{COCs}$ were cultured in the db-cAMP- and hMG-supplemented medium for $20 \mathrm{~h}$ at $39^{\circ} \mathrm{C}$ in a $100 \%$ water-saturated atmosphere of $5 \% \mathrm{CO}_{2}$ and $95 \%$ air. The oocytes were then cultured for 22 to $24 \mathrm{~h}$ in fresh maturation medium that did not contain db-cAMP and hMG (Skrzyszowska et al., 2008; Samiec and Skrzyszowska, 2010, 2013; Samiec et al., 2013).

After maturation, expanded cumulus oophorus and corona cells were completely removed by vigorous pipetting of the COCs in the presence of $0.5 \mathrm{mg} \mathrm{mL}^{-1}$ (50 IU $\mathrm{mL}^{-1}$ ) bovine testis-derived hyaluronidase in $500 \mu \mathrm{L}$ of HEPES-buffered TCM 199 for 1 to $2 \mathrm{~min}$. The in vitro-matured, metaphase II (MII)-stage oocytes, which were selected on the basis of accepted morphological criteria, including evenly granulated, dark cytoplasm, intact plasma membrane and the presence of distinctly extruded first polar bodies (polocytes), provided a source of recipient cells for exogenous cell nuclei for the somatic cloning procedure (Samiec and Skrzyszowska, $2012 \mathrm{a}, \mathrm{b}$ ).

\section{Isolation, in vitro culture and mitotic cycle synchronization of porcine fi- broblast cells}

Foetal cells were isolated from conceptuses $(9.0 \mathrm{~cm}$ in length) following removal of their heads and internal organs. The foetuses were obtained from a slaughterhouse; that is why, their age and breed were unknown. Adult fibroblast cells were collected from an ear-skin biopsy taken from a 5-month-old (i.e., pubertal) gilt. Foetal bodyderived or adult tissue samples were cut into small pieces using a tissue chopper $(0.5 \mathrm{~mm})$. The resultant tissue explants were placed in a BD Falcon cell culture flask (Becton Dickinson Co., Franklin Lakes, NJ, USA) filled with a small volume of Dulbecco's Modified Eagle's Medium (DMEM, Gibco Invitrogen Co., Paisley, Scotland, UK) to wet the bottom of the flask, but not enough volume to cause the tissue pieces to float. During the first 2 to 3 days of incubation, a few drops 
of medium were added every 2 to $3 \mathrm{~h}$, and more medium was added gradually when the pieces had firmly attached to the bottom of the culture flask. The cultures were replenished 2 to 3 times per week. Primary cultures of dermal fibroblasts were grown in modified Dulbecco's Minimum Essential Medium supplemented with 10\% foetal bovine serum (FBS), $5 \mathrm{ng} \mathrm{mL} \mathrm{m}^{-1}$ recombinant human basic fibroblast growth factor (rh-bFGF), 2 mM Eagle's Minimum Essential Medium (MEM)-based non-essential amino acid (NEAA) solution, $2 \mathrm{mM} \mathrm{L}$-glutamine, $0.36 \mathrm{mM}$ sodium pyruvate, and $1 \%$ antibiotic-antimycotic solution (AAS). After removal of the explants (Days 5 to 6 ), monolayers of fibroblast cells were digested into single cells using cell detachment buffer comprised of $0.25 \%$ trypsin- $0.01 \%$ EDTA. The cells were subsequently cultured to total confluence and then passaged at least twice. The cells harvested from the flasks by trypsinization were washed in $10 \mathrm{~mL}$ manipulation medium (HEPESbuffered Tissue Culture Medium 199) enriched with 10\% FBS and centrifuged at $200 \times \mathrm{g}$ for $10 \mathrm{~min}$. The cell pellet was then suspended in FBS containing 9\% dimethyl sulfoxide (DMSO) before freezing in a Minicool freezer (Minicool 40 PC; Air Liquide, Bussy-Saint-Georges, France). The cryopreserved donor cells were thawed at $37^{\circ} \mathrm{C}$, and $200 \mu \mathrm{L}$ of FBS was added. The suspension was incubated at room temperature for $10 \mathrm{~min}$, and then $800 \mu \mathrm{L}$ of cell culture medium was added (Skrzyszowska et al., 2008; Samiec and Skrzyszowska, 2010, 2012 a).

Before their use for somatic cell nuclear transfer (SCNT), the frozen/thawed clonal cell lines (cell strains) of foetal or adult dermal fibroblasts were cultured in vitro to total confluence (in the medium supplemented with $10 \% \mathrm{FBS}$ ) to synchronize their mitotic cycle at the G1/G0 stages by initiating 24- to 48-h contact inhibition of their migration and proliferative growth (Samiec and Skrzyszowska, 2012 b, 2013; Samiec et al., 2012, 2013). The second method used for synchronization of the cell cycle at the G0/G1 stages was the culture of the subconfluent fibroblast cell lines under the conditions of 3-4-Day serum deprivation/starvation (i.e., reduction of FBS concentration in the medium from $10 \%$ up to $0.5 \%$ ) (Skrzyszowska et al., 2006; Samiec et al., 2013).

After the cell cycle synchronization had been completed, the cultured clonal fibroblast cell lines (between passages 2 and 7) were trypsinized, followed by centrifugation at $300 \times \mathrm{g}$ for $5 \mathrm{~min}$. The supernatant was subsequently removed, and $50 \mu \mathrm{L}$ of the manipulation medium enriched with $4 \mathrm{mg} \mathrm{mL}^{-1} \mathrm{BSA}-\mathrm{V}$ was added.

\section{Preparation and flow cytometric analysis of fibroblast cell lines for apoptosis and cell cycle}

Apoptosis and cell cycle were examined simultaneously according to cellular nDNA content measurement method (Darzynkiewicz et al., 1992, 1994; Gorczyca et al., 1998). Briefly, contact-inhibited or serum-deprived fibroblast cells that had been harvested by trypsinization were fixed in ice-cold $70 \%$ ethanol and subjected to the first centrifugation. Subsequently, the fixed fibroblast cells were rinsed with $\mathrm{CaCl}_{2}$ - and $\mathrm{MgCl}_{2}$-depleted phosphate-buffered saline (PBS; Biomed, Lublin, Poland), recentrifuged and resuspended in nDNA extraction buffer $(\mathrm{pH}=7.8)$, which was composed of $96 \mathrm{~mL}$ of $0.2 \mathrm{M} \mathrm{Na}_{2} \mathrm{HPO}_{4}$ and $4 \mathrm{~mL}$ of $0.1 \mathrm{M}$ citric acid. After 5-min treatment with nDNA extraction buffer at room temperature, the fibrob- 
last cells were centrifuged de novo, followed by exposure to DNA staining and RNA digestion solution for $30 \mathrm{~min}$. This solution was comprised of $20 \mu \mathrm{g} \mathrm{mL}-1$ propidium iodide (PI; Molecular Probes, Eugene, OR, USA) at a concentration of $1 \mathrm{mg} \mathrm{mL}{ }^{-1}(1.5 \mathrm{mM})$ in distilled water $\left(\mathrm{dH}_{2} \mathrm{O}\right)$ and $0.2 \mathrm{mg} \mathrm{mL}^{-1}$ bovine pancreatic RNase A (Clontech; Becton, Dickinson and Co., BD Biosciences, Palo Alto, CA, USA), which were both diluted in $10 \mathrm{~mL}$ of PBS (Samiec et al., $2009 \mathrm{a}, \mathrm{b}$ ). The fibroblast cells that had been previously dyed with PI and had been simultaneously deprived of RNA molecules were analysed on a Coulter Elite flow cytometer (Model EPICS Elite ESP; Beckman-Coulter Ltd., Luton, UK) by reading nDNA fluorescence in the red band $\left(\lambda_{\max }=675 \mathrm{~nm}\right)$. There were diagnosed no less than $1 \times 10^{4}$ cells for each cell sample. Identification and quantification of internucleosomal fragmentation of genomic DNA in late-apoptotic cells (i.e., hypodiploidy) as well as the calculations of cell cycle phases in non-apoptotic cells were performed using the ModFit LT (version 3.2) software (Verity Software House; VSH, USA) (Samiec et al., 2009 a, b).

The nuclear donor cells were derived from such cell line populations, the representative (random) samples of which had been analysed for both cell cycle and late apoptotic cell death through the non-vital DNA fluorescent, i.e., PI-mediated staining and subsequent flow cytometry (FACS; fluorescence-activated cell sorting).

\section{Production of porcine nuclear-transferred embryos \\ Enucleation of oocytes}

Cumulus-denuded MII-stage oocytes were incubated in the maturation medium supplemented with $0.4 \mu \mathrm{g} \mathrm{mL} \mathrm{mL}^{-1}$ demecolcine/colcemid (DMCC; N-deacetyl$\mathrm{N}$-methylcolchicine) and $0.05 \mathrm{M}$ sucrose for $1 \mathrm{~h}$ at $39^{\circ} \mathrm{C}$. Afterwards, the treated oocytes were transferred into a glass micromanipulation chamber filled with TCM 199 with addition of $4 \mathrm{mg} \mathrm{mL}-1$ BSA-V, $5 \mu \mathrm{g} \mathrm{mL} \mathrm{mL}^{-1}$ cytochalasin B (CB) and $0.4 \mu \mathrm{g} \mathrm{mL}^{-1} \mathrm{DMCC}$. Maternal chromosomes (metaphase plates), which had been allocated into chemically induced protrusion of plasma membrane, were removed microsurgically (Yin et al., 2002; Kawakami et al., 2003; Kawano et al., 2004). Enucleation was accomplished by gently aspirating the ooplasmic cone, which contained condensed chromosome cluster, with the aid of a bevelled micropipette of 20- to 25- $\mu \mathrm{m}$ external diameter (Skrzyszowska et al., 2008; Samiec and Skrzyszowska, 2010, 2012 a). Following enucleation, the resulting ooplasts were washed extensively in HEPES-buffered TCM 199/BSA-V and held in this CB- and DMCC-free medium until the subzonal microinjection of intact nuclear donor cells was performed.

\section{Reconstruction and activation of oocytes}

Reconstruction of enucleated oocytes (ooplasts) was achieved by their electrofusion with adult cutaneous or foetal fibroblast cells. Nuclear donor cells were selected under Nomarski-type differential interference contrast (DIC) optics according to their size and shape. Only the single somatic cells that exhibited a spherical shape and a smooth, intact surface of plasma membrane were microinjected subzonally into perivitelline space of the previously enucleated oocytes. The 
resulting fibroblast cell-ooplast couplets were transferred to a BTX fusion/activation chamber (BTX Model 450; Harvard Apparatus, Holliston, MA, USA), which was positioned between two parallel wire electrodes $0.5 \mathrm{~mm}$ apart. The chamber was filled with electroporation medium, which was composed of $0.3 \mathrm{M} \mathrm{D}$-mannitol enriched with $1.0 \mathrm{mM} \mathrm{CaCl}_{2}, 0.1 \mathrm{mM} \mathrm{MgSO}_{4}$ and $0.2 \mathrm{mg} \mathrm{mL}^{-1}$ fatty acid-free BSA (FAF-BSA). Somatic cell-ooplast complexes were simultaneously fused and activated using two consecutive DC pulses of $1.2 \mathrm{kV} \mathrm{cm}^{-1}$ for $60 \mu \mathrm{s}$ each that were delivered by a BTX Electro Cell Manipulator 200 (BTX ECM Model 200; Biotechnologies \& Experimental Research, Inc., San Diego, CA, USA) (Skrzyszowska et al., 2008; Samiec and Skrzyszowska, 2012 a, b; Samiec et al., 2012, 2013).

\section{In vitro culture of reconstructed embryos}

Cloned embryos were cultured in 50- $\mu \mathrm{L}$ droplets of North Carolina State University-23 (NCSU-23) medium supplemented with 4 mg mL ${ }^{-1}$ BSA-V, 1\% MEM-nonessential amino acid solution (MEM-NEAA) and 2\% MEM-essential amino acid solution (MEM-EAA) that had been overlaid with light mineral oil. The number of embryos per droplet of culture medium ranged from 20 to 30 . After 72 to $96 \mathrm{~h}$ of in vitro culture, the cleaved embryos were transferred into a $50-\mu \mathrm{L}$ drop of NCSU-23/ BSA-V/MEM-NEAA/MEM-EAA medium enriched with $10 \% \mathrm{FBS}$ for an additional $72 \mathrm{~h}$. The reconstructed embryos were incubated at $39^{\circ} \mathrm{C}$, in a $100 \%$ water-saturated atmosphere of $5 \% \mathrm{CO}_{2}$ and $95 \%$ air. At the end of the in vitro culture period (Days 6 to 7), the embryos were evaluated morphologically for morula and blastocyst formation rates (Samiec and Skrzyszowska, 2010, 2012 a, 2013).

\section{Experimental protocol}

In the first series of experiments, the frequency distributions for the phases of mitotic cycle of non-apoptotic cells and the proportions of late-apoptotic cells in the populations of contact-inhibited and serum-starved adult cutaneous and foetal fibroblast cells were estimated on the basis of flow cytometric diagnostics.

In the second series of experiments, the in vitro developmental capabilities of porcine NT embryos reconstructed with either adult cutaneous or foetal fibroblast cells, originating from contact-inhibited and serum-deprived cell lines that were analysed for apoptosis and cell cycle by flow cytometry, were compared.

\section{Statistical analysis}

The chi-square test was applied to compare the rates of both cycling cells at different stages of mitotic cycle and non-cycling (apoptotic) cells between the subpopulations of contact-inhibited or serum-starved adult cutaneous and foetal fibroblast cells. This test was also used for estimation of the statistical variations in the percentages of successfully reconstructed oocytes, the percentages of cleaved embryos and the percentages of embryos at morula and blastocyst stages between different experimental groups including nuclear donor cell type and cell cycle synchronization method. 


\section{Results}

\section{The use of flow cytometry for simultaneous analysis of cell cycle and apopto- sis in contact-inhibited and serum-starved fibroblast cell lines}

Cytometric (FACS) analysis of mitotic cell cycle together with the detection of late-apoptotic cell fractions with hypodiploid number of nDNA molecules (representing the sub-G1/G0 or pre-G1/G0 peak in the DNA histogram) revealed the following mean frequency distributions for the stages of mitotic cycle of non-apoptotic cells and the proportions of the cells at the destruction phase of apoptosis in the diagnosed contact-inhibited populations of fibroblasts. Briefly, out of all the adult dermal fibroblast cells that were analysed, 53.6\% were cycling. Simultaneously, up to $46.4 \%$ cells reached the late stage of programmed cell death. In turn, from among the non-apoptotic cells, an average of $85.2 \%$ were at the G0/G1 stages of the cell cycle, $14.4 \%$ at the S stage, and only $0.4 \%$ at the G2/M stages of cell cycle. Similarly, $54.7 \%$ foetal fibroblast cells were cycling and the late-apoptotic changes occurred among $45.3 \%$ cells. Out of cycling cells, $82.1 \%$ represented the G0/G1 stages, $17.0 \%$ the S stage, and only $0.9 \%$ the G2/M stages.

There were also found the following mean frequency distributions for the stages of cell division cycle and the late phase of apoptosis in the serum-deprived fibroblast cells analysed by FACS. The proportion of cycling adult ear skin-derived fibroblast cells was $91.8 \%$, but only $8.2 \%$ cells displayed the late symptoms of physiological suicide cell death. Among the cycling cell subpopulations, $87.0 \%$ remained at the G0/G1 stages, $3.8 \%$ at the S stage and $9.2 \%$ at the G2/M stages. In turn, up to $91.5 \%$ foetal fibroblast cells retained the ability to undergo the active mitotic divisions, but the late stage of apoptosis began in only $8.5 \%$ cells. Out of non-apoptotic foetal fibroblast cells that underwent the progression of mitotic cycle, $81.8 \%$ reached the G0/G1 stages of interphase, $5.4 \%$ the $\mathrm{S}$ stage of interphase, and $12.8 \%$ entered the $\mathrm{G} 2 / \mathrm{M}$ stages.

Table 1. Effect of the mitotic cycle synchronization strategy on the mean frequency distribution for the stages of cell division cycle and the late phase of apoptosis in the flow cytometrically analysed adult cutaneous fibroblast cells

\begin{tabular}{l|c|c|c|c}
\hline \multirow{2}{*}{$\begin{array}{c}\text { Method of cell cycle } \\
\text { synchronization }\end{array}$} & \multicolumn{2}{|c|}{ Percentage of cycling cells at } & \multirow{2}{*}{$\begin{array}{c}\text { Percentage of late-apoptotic } \\
\text { hypodiploid cells }\end{array}$} \\
\cline { 2 - 3 } Contact inhibition & G0/G1 stages & S stage & G2/M stages & $46.4 \% \mathrm{~A}$ \\
& \multicolumn{4}{c}{$53.6 \% \mathrm{~A}$} \\
Serum starvation & $85.2 \% \mathrm{a}$ & $14.4 \% \mathrm{a}$ & $0.4 \% \mathrm{a}$ & \\
& & $91.8 \% \mathrm{~B}$ & & \\
& $87.0 \% \mathrm{a}$ & $3.8 \% \mathrm{~b}$ & $9.2 \% \mathrm{~b}$ & \\
\hline
\end{tabular}

a, a - Values with identical letters within the same column do not vary significantly ( $\mathrm{P} \geq 0.05$, chi-square test). Number of replicates $=3$.

$\mathrm{a}, \mathrm{b}$ - Values with different letters within the same column differ significantly $(\mathrm{P}<0.05$, chi-square test). Number of replicates $=3$.

A, B - Values with different letters within the same column vary significantly $(\mathrm{P}<0.001$, chi-square test). Number of replicates $=3$. 
Statistical variability in the percentages of the cells remaining at the G0/G1 stages, the percentages of the cells entering the $\mathrm{S}$ stage and G2/M stages as well as in the frequencies of occurrence of late-phase apoptotic cell death was measured between the subpopulations of contact-inhibited and serum-starved adult cutaneous fibroblast cells. This measurement was presented in Table 1.

The levels of statistical diversification related not only to the rates of cells reaching the $\mathrm{G} 0 / \mathrm{G} 1, \mathrm{~S}$ and $\mathrm{G} 2 / \mathrm{M}$ stages, but also to the incidence of late-phase apoptosis were calculated between the fractions of contact-inhibited and serum-starved foetal fibroblast cells. These calculations were included in Table 2.

Table 2. Effect of the mitotic cycle synchronization strategy on the mean frequency distribution for the stages of cell division cycle and the late phase of apoptosis in the flow cytometrically analysed foetal fibroblast cells

\begin{tabular}{l|c|c|c|c}
\hline Method of cell cycle & \multicolumn{3}{|c|}{ Percentage of cycling cells at } & Percentage of late-apoptotic \\
synchronization & G0/G1 stages & S stage & G2/M stages & $45.3 \% \mathrm{~A}$ \\
hypodiploid cells
\end{tabular}

a, a - Values with identical letters within the same column do not vary significantly ( $\mathrm{P} \geq 0.05$, chi-square test). Number of replicates $=3$.

A, B - Values with different letters within the same column differ significantly $(\mathrm{P}<0.001$, chi-square test $)$. Number of replicates $=3$.

C, D - Values with different letters within the same column vary significantly $(\mathrm{P}<0.01$, chi-square test $)$. Number of replicates $=3$.

\section{Production of porcine cloned embryos using contact-inhibited and serum- starved fibroblast cells}

In Table 3, the preimplantation developmental capacities of cloned pig embryos, including the cleavage activity, morula and blastocyst yields, were compared between the two experimental groups, which differed by the nuclear donor cell type. These groups involved the enucleated oocytes that were reconstituted with contactinhibited adult dermal fibroblast cell nuclei or foetal fibroblast cell nuclei.

Table 3. Comparison of the in vitro developmental capabilities between cloned pig embryos reconstructed with the cell nuclei of contact-inhibited fibroblast cells of different origin

\begin{tabular}{|c|c|c|c|c|c|}
\hline \multirow{2}{*}{$\begin{array}{l}\text { Origin of contact-inhibited } \\
\text { nuclear donor fibroblast cells }\end{array}$} & \multicolumn{3}{|c|}{ Number of oocytes/embryos } & \multicolumn{2}{|c|}{ Development to } \\
\hline & electrofused & $\begin{array}{c}\text { cultured } \\
(\%)\end{array}$ & $\begin{array}{c}\text { cleaved } \\
(\%)\end{array}$ & $\begin{array}{c}\text { morulae } \\
(\%)\end{array}$ & $\begin{array}{c}\text { blastocysts } \\
(\%)\end{array}$ \\
\hline $\begin{array}{l}\text { Adult cutaneous fibroblast } \\
\text { cells }\end{array}$ & 303 & $\begin{array}{l}278 / 303 \\
(91.7) \mathrm{a}\end{array}$ & $\begin{array}{l}207 / 278 \\
(74.5) \mathrm{A}\end{array}$ & $\begin{array}{l}169 / 278 \\
(60.8) \mathrm{C}\end{array}$ & $\begin{array}{l}76 / 278 \\
(27.3) \mathrm{a}\end{array}$ \\
\hline Foetal fibroblast cells & 314 & $\begin{array}{l}296 / 314 \\
(94.3) \mathrm{a}\end{array}$ & $\begin{array}{l}255 / 296 \\
(86.1) \mathrm{B}\end{array}$ & $\begin{array}{l}223 / 296 \\
(75.3) \mathrm{D}\end{array}$ & $\begin{array}{l}108 / 296 \\
(36.5) \mathrm{b}\end{array}$ \\
\hline
\end{tabular}

a, a - Values with identical letters within the same column do not vary significantly ( $\mathrm{P} \geq 0.05$, chi-square test). Number of replicates $=8$.

$\mathrm{a}, \mathrm{b}$ - Values with different letters within the same column differ significantly $(\mathrm{P}<0.05$, chi-square test). Number of replicates $=8$.

A, B - Values with different letters within the same column vary significantly $(\mathrm{P}<0.01$, chi-square test $)$. Number of replicates $=8$.

C, D - Values with different letters within the same column differ significantly $(\mathrm{P}<0.001$, chi-square test $)$. Number of replicates $=8$. 
In Table 4, the in vitro developmental potential of NT embryos that were derived from serum-starved adult dermal and foetal fibroblast cells was presented.

Table 4. Comparison of the in vitro developmental capabilities between cloned pig embryos reconstructed with the cell nuclei of serum-starved fibroblast cells of different origin

\begin{tabular}{|c|c|c|c|c|c|}
\hline \multirow{2}{*}{$\begin{array}{l}\text { Origin of serum-starved } \\
\text { nuclear donor fibroblast } \\
\text { cells }\end{array}$} & \multicolumn{3}{|c|}{ Number of oocytes/embryos } & \multicolumn{2}{|c|}{ Development to } \\
\hline & electrofused & $\begin{array}{l}\text { cultured } \\
(\%)\end{array}$ & $\begin{array}{l}\text { cleaved } \\
(\%)\end{array}$ & $\begin{array}{l}\text { morulae } \\
(\%)\end{array}$ & $\begin{array}{c}\text { blastocysts } \\
(\%)\end{array}$ \\
\hline $\begin{array}{l}\text { Adult cutaneous fibroblast } \\
\text { cells }\end{array}$ & 309 & $\begin{array}{l}265 / 309 \\
(85.8) \mathrm{a}\end{array}$ & $\begin{array}{l}164 / 265 \\
(61.9) \mathrm{A}\end{array}$ & $\begin{array}{l}121 / 265 \\
(45.7) \mathrm{C}\end{array}$ & $\begin{array}{l}46 / 265 \\
(17.4) \mathrm{a}\end{array}$ \\
\hline Foetal fibroblast cells & 298 & $\begin{array}{l}261 / 298 \\
(87.6) \mathrm{a}\end{array}$ & $\begin{array}{l}192 / 261 \\
(73.6) \mathrm{B}\end{array}$ & $\begin{array}{l}165 / 261 \\
(63.2) \mathrm{D}\end{array}$ & $\begin{array}{c}67 / 261 \\
(25.7) b\end{array}$ \\
\hline
\end{tabular}

a, a - Values with identical letters within the same column do not vary significantly ( $\mathrm{P} \geq 0.05$, chi-square test). Number of replicates $=8$.

$\mathrm{a}, \mathrm{b}$ - Values with different letters within the same column differ significantly $(\mathrm{P}<0.05$, chi-square test). Number of replicates $=8$.

A, B - Values with different letters within the same column vary significantly $(\mathrm{P}<0.01$, chi-square test). Number of replicates $=8$.

C, D - Values with different letters within the same column differ significantly $(\mathrm{P}<0.001$, chi-square test). Number of replicates $=8$.

Table 5 shows the statistical variations between developmental outcomes of NT embryos reconstructed with adult dermal fibroblast cells, the cell cycle of which was synchronized at the G0/G1 phases with the use of two different strategies (contact inhibition and serum deprivation).

Table 5. Effect of the cell cycle synchronization method on the in vitro developmental competencies of porcine nuclear-transferred embryos descended from adult cutaneous fibroblast cells

\begin{tabular}{|c|c|c|c|c|c|}
\hline \multirow{2}{*}{$\begin{array}{c}\text { Approach to } \\
\text { artificial synchronization } \\
\text { of mitotic cycle }\end{array}$} & \multicolumn{3}{|c|}{ Number of oocytes/embryos } & \multicolumn{2}{|c|}{ Development to } \\
\hline & enucleated & $\begin{array}{l}\text { electrofused } \\
(\%)\end{array}$ & $\begin{array}{c}\text { cleaved } \\
(\%)\end{array}$ & $\begin{array}{c}\text { morulae } \\
(\%)\end{array}$ & $\begin{array}{c}\text { blastocysts } \\
(\%)\end{array}$ \\
\hline Contact inhibition & 303 & $\begin{array}{l}278 / 303 \\
(91.7) \mathrm{a}\end{array}$ & $\begin{array}{l}207 / 278 \\
(74.5) \mathrm{A}\end{array}$ & $\begin{array}{l}169 / 278 \\
(60.8) \mathrm{A}\end{array}$ & $\begin{array}{l}76 / 278 \\
(27.3) \mathrm{a}\end{array}$ \\
\hline Serum starvation & 309 & $\begin{array}{l}265 / 309 \\
(85.8) \mathrm{a}\end{array}$ & $\begin{array}{l}164 / 265 \\
(61.9) \mathrm{B}\end{array}$ & $\begin{array}{l}121 / 265 \\
(45.7) \mathrm{B}\end{array}$ & $\begin{array}{c}46 / 265 \\
(17.4) b\end{array}$ \\
\hline
\end{tabular}

a, a - Values with identical letters within the same column do not vary significantly ( $\mathrm{P} \geq 0.05$, chi-square test). Number of replicates $=8$.

$\mathrm{a}, \mathrm{b}$ - Values with different letters within the same column differ significantly $(\mathrm{P}<0.05$, chi-square test). Number of replicates $=8$.

A, B - Values with different letters within the same column vary significantly $(\mathrm{P}<0.001$, chi-square test). Number of replicates $=8$.

In Table 6, the abilities to divide and to reach the morula and blastocyst stages were estimated for cloned embryos descended from enucleated oocytes receiving foetal fibroblast cell nuclei. These estimations were calculated according to various 
approaches to the artificial synchronization of mitotic cycle (contact inhibition and serum starvation).

Table 6. Effect of the cell cycle synchronization method on the in vitro developmental competencies of porcine nuclear-transferred embryos descended from foetal fibroblast cells

\begin{tabular}{|c|c|c|c|c|c|}
\hline \multirow{2}{*}{$\begin{array}{c}\text { Approach to } \\
\text { artificial synchronization } \\
\text { of mitotic cycle }\end{array}$} & \multicolumn{3}{|c|}{ Number of oocytes/embryos } & \multicolumn{2}{|c|}{ Development to } \\
\hline & enucleated & $\begin{array}{c}\text { electrofused } \\
(\%)\end{array}$ & $\begin{array}{c}\text { cleaved } \\
(\%)\end{array}$ & $\begin{array}{c}\text { morulae } \\
(\%)\end{array}$ & $\begin{array}{c}\text { blastocysts } \\
(\%)\end{array}$ \\
\hline Contact inhibition & 314 & $\begin{array}{l}296 / 314 \\
(94.3) \mathrm{a}\end{array}$ & $\begin{array}{l}255 / 296 \\
(86.1) \mathrm{A}\end{array}$ & $\begin{array}{l}223 / 296 \\
(75.3) \mathrm{C}\end{array}$ & $\begin{array}{l}108 / 296 \\
(36.5) \mathrm{C}\end{array}$ \\
\hline Serum starvation & 298 & $\begin{array}{l}261 / 298 \\
(87.6) \mathrm{a}\end{array}$ & $\begin{array}{l}192 / 261 \\
(73.6) \mathrm{B}\end{array}$ & $\begin{array}{l}165 / 261 \\
(63.2) \mathrm{D}\end{array}$ & $\begin{array}{c}67 / 261 \\
(25.7) \mathrm{D}\end{array}$ \\
\hline
\end{tabular}

a, a - Values with identical letters within the same column do not vary significantly ( $\mathrm{P} \geq 0.05$, chi-square test). Number of replicates $=8$.

A, B - Values with different letters within the same column differ significantly $(\mathrm{P}<0.001$, chi-square test $)$. Number of replicates $=8$.

C, D - Values with different letters within the same column vary significantly $(\mathrm{P}<0.01$, chi-square test). Number of replicates $=8$.

The effect of the origin of contact-inhibited or serum-depleted nuclear donor fibroblast cells on both the frequencies of cleavage divisions and the morula/blastocyst formation rates of NT pig embryos turned out to be statistically significant (Tables 3 and 4). Similarly, significant differences were noticed in the capabilities of cloned embryos to cleave and to complete their in vitro development to the morula and blastocyst stages between the subgroups encompassing diverse methods used to ectopically synchronize the cell cycle of cultured adult cutaneous and foetal fibroblast cells at the G0/G1 phases (Tables 5 and 6).

\section{Discussion}

The use of flow cytometry for simultaneous analysis of cell cycle and apoptosis in contact-inhibited and serum-starved fibroblast cell lines

The cytometric (FACS) analysis for cell division cycle of in vitro cultured fibroblast cells confirmed the high efficiency of the artificial synchronization of mitotic cycle at the G0/G1 stages (ranging from approximately $82 \%$ to $87 \%$ ) when applying the methods of contact inhibition of migration and proliferative growth of the cells in the conditions of a total confluence state or 3-4-Day serum deprivation. Moreover, the proportion of apoptotic cells in the flow cytometrically-diagnosed contactinhibited fibroblast cell populations was higher compared with the rate of apoptotic/ necrotic cells in the intra vitam analysed cell populations (46\% vs. 10 to $30 \%$ among adult dermal fibroblast cells and $45 \%$ vs. 20 to $40 \%$ among foetal fibroblast cells) (Samiec and Skrzyszowska, 2012 a, 2013; Samiec et al., 2013). Nonetheless, for the cytometrically-diagnosed serum-starved fibroblast cell populations, the proportion of apoptotic and/or necrotic cells was significantly lower than that for the vitally 
analysed cell populations ( $8 \%$ vs. 15-20\% among adult cutaneous fibroblast cells and $9 \%$ vs. 20-25\% among foetal fibroblast cells) (Samiec et al., 2013).

In contrast to our experiments, in which the percentage of foetal fibroblast cells at the G0/G1 phases of mitotic cycle (approximately 82\%) did not differ significantly between the contact-inhibited and the serum-starved cell subpopulations, in the study by Park et al. (2010), 3-Day serum deprivation led to obtaining more abundant cell fractions arrested at the G0/G1 stages (nearly 88\%) compared with contact inhibition of migration and proliferative activity of fibroblast cells (over 76\%). But, the study by Boquest et al. (1999) showed, similarly to the results of current investigation, that the synchronization of mitotic cycle of foetal fibroblast cells by contact inhibition of cultured cells under the conditions of a total confluence can be alternative to 5-Day serum deprivation, because its efficacy measured with the proportion of cells at the G0/G1 stages is comparable (85\% vs. $88 \%$ ). Nevertheless, in our present experiments, we observed that the percentage of the cells with advanced morphological changes (i.e., rough, corrugated/folded or invaginated/retracted extracellular surface of plasma membrane and presence of the plasmalemmal blebbing associated with the cytoplasmic shrinkage) that were related to the late destructive phase of apoptosis increased, prolonging from $24 \mathrm{~h}$ to $48-72 \mathrm{~h}$ the subculture period of the fibroblast cells under the $100 \%$ confluence conditions. For this reason, the proportion of apoptotic fibroblast cells subjected to contact inhibition of their migration and proliferative growth could reach so high a level (approximately 45\%). It can be explained by an elevated trophic competitiveness, diminished DNA transcriptional and mRNA translational activities and thereby decreased diameter/size of the cells under the conditions of their more and more limited spatial accessibility to mitogenic factors and energy components originating from the supplementation of culture medium with foetal bovine serum (Boquest et al., 1999; Kues et al., 2002; Lee and Piedrahita, 2002; Skrzyszowska et al., 2006; Mohana Kumar et al., 2007). That is why, the viability of cultured (contact-inhibited) fibroblast cells was considerably reduced, which resulted from the irreversible cell division block at the G1 stage and induction of molecular scenario of apoptosis (Anger et al., 2003; Gómez et al., 2003; Hashem et al., 2007; Park et al., 2010).

\section{Production of porcine cloned embryos using contact-inhibited and serum- starved fibroblast cells}

The results of our study have clearly demonstrated that regardless of the type of fibroblast cells used as a source of nuclear donors for somatic cell cloning in pigs, the synchronization of cell division cycle at the G0/G1 stages that was triggered by contact inhibition of migration and proliferative activity contributes to significant enhancements in the embryo cleavage activity and morula/blastocyst formation rates as compared to the serum starvation. Similarly to our previous investigations (Samiec and Skrzyszowska, 2010, 2012 a), in the current study, the abilities of porcine NT embryos derived from non-apoptotic contact-inhibited foetal fibroblast cells to reach the blastocyst stage were considerably higher than those of NT embryos reconstituted with adult cutaneous fibroblast cells (nearly $47 \%$ vs. $35 \%$, over $33 \%$ vs. $24 \%$ and $37 \%$ vs. $27 \%$, respectively). Lee et al. (2003 b) also reported that the cloning 
competence of serum-deprived foetal fibroblast cells that was measured with blastocyst yield (almost 16\%) increased twice as compared to the competence of adult dermal fibroblast cells (approximately $8 \%$ blastocysts). Nonetheless, we achieved significantly higher blastocyst formation rates after reconstruction of enucleated pig oocytes with either serum-starved foetal or adult cutaneous fibroblast cell nuclei (26\% and $17 \%$, respectively).

Altogether, the flow cytometric analysis of cultured foetal or adult dermal fibroblasts confirmed the high efficacy of the inducible synchronization of cell cycle at the G0/G1 stages following application of the contact inhibition or serum starvation strategies. Furthermore, contact inhibition of migration and mitotic activity of adult cutaneous fibroblast cells and foetal fibroblast cells led to considerably higher morula and blastocyst yields of porcine NT embryos under in vitro culture compared to serum deprivation of both types of fibroblast cells. Nonetheless, irrespective of the approaches used for ectopic synchronization of the cell division cycle of nuclear donor somatic cells at the G0/G1 phases, developmental capabilities to reach the morula and blastocyst stages for cloned pig embryos that had been produced using foetal fibroblast cells were significantly higher than those for embryos that had been generated using adult cutaneous fibroblast cells.

\section{References}

Anger M., Kues W.A., Klima J., Mielenz M., Kubelka M., Motlik J., Esner M., D vorak P., C a r n w a r th J.W., N i e m a n n H. (2003). Cell cycle dependent expression of Plk1 in synchronized porcine fetal fibroblasts. Mol. Reprod. Dev., 65: 245-253.

Archer G.S., Dind ot S., Friend T.H., Walker S., Z a unbrecher G., Law horn B., Pie d r a h i t a J.A. (2003). Hierarchical phenotypic and epigenetic variation in cloned swine. Biol. Reprod., 69: 430-436.

B o que st A.C., D a y B.N., P r a the r R.S. (1999). Flow cytometric cell cycle analysis of cultured porcine fetal fibroblast cells. Biol. Reprod., 60: 1013-1019.

Cheng D., Li Z., Li u Y., G a o Y., Wang H. (2012). Kinetic analysis of porcine fibroblast reprogramming toward pluripotency by defined factors. Cell. Reprogram., 14: 312-323.

Darzynki ew ic z Z., Bruno S., Del B ino G. (1992). Features of apoptotic cells measured by flow cytometry. Cytometry, 13: 795-808.

D a r z y n k i e w i c z Z., Li X., G on g J. (1994). Assays of cell viability: discrimination of cells dying by apoptosis. Methods Cell Biol., 41: 15-38.

Estaquier J., Taneka M., Suda T., Nagata S., Golstein P., A meis en J.C. (1996). Fas-mediated apoptosis of $\mathrm{CD}^{+}$and $\mathrm{CD}^{+} \mathrm{T}$ cells from human immunodeficiency virus-infected persons: differential in vitro preventive effect of cytokines and protease antagonists. Blood, 87: 4959-4966.

Fra s c h S.C., H e n s on P.M., N a g a o s a K., F e s s le r M.B., B or r e ga a rd N., B rat to n D.L. (2004). Phospholipid flip-flop and phospholipid scramblase 1 (PLSCR1) co-localize to uropod rafts in formylated Met-Leu-Phe-stimulated neutrophils. J. Biol. Chem., 279: 17625-17633.

Gó m e z M.C., J e n k in s J.A., G ir a ld o A., H arris R.F., King A., D re s s e r B.L., P o pe C.E. (2003). Nuclear transfer of synchronized African wild cat somatic cells into enucleated domestic cat oocytes. Biol. Reprod., 69: 1032-1041.

Gó m e z M.C., P o p e C.E., Ló p e z M., D u ma s C., G i raldo A., D re s s e r B.L. (2006). Chromosomal aneuploidy in African Wildcat somatic cells and cloned embryos. Cloning Stem Cells, 8: 69-78. 
Gorczyca W., Melamed M.R., Darzynkiewicz Z. (1998). Analysis of apoptosis by flow cytometry. In: Methods in Molecular Biology, Vol. 91. Flow Cytometry Protocols, Jaroszeski M.J., Heller R. (eds). Humana Press, Totowa, New Jersey, USA, pp. 217-238.

Griffit h T.S., B run ner T., F l e t ch er S.M., Gre en D.R., F e r g u s o n T.A. (1995). Fas ligandinduced apoptosis as a mechanism of immune privilege. Science, 270: 1189-1192.

Harrison S., B oquest A., Grupen C., Fa ast R., Guildolin A., Giannakis C., Crocker L., McIlfatrick S., A shman R., Wengle J., Lyons I., Tolstoshev P., Cowan P., Robins A., O 'C onnell P., D' A p ic e A.J.F., Nottle M. (2004). An efficient method for producing $\alpha(1,3)$-galactosyltransferase gene knockout pigs. Cloning Stem Cells, 6: 327-331.

Hashem M.A., Bhandari D.P., Kang S.K., Lee B.C. (2007). Cell cycle analysis and interspecies nuclear transfer of in vitro cultured skin fibroblasts of the Siberian tiger (Panthera tigris Altaica). Mol. Reprod. Dev., 74: 403-411.

Hyun S.H., Lee G.S., Kim D.Y., Kim H.S., Lee S.H., Kim S., Lee E.S., Lim J.M., K a n g S.K., L e e B.C., H w an g W.S. (2003 a). Effect of maturation media and oocytes derived from sows or gilts on the development of cloned pig embryos. Theriogenology, 59: 1641-1649.

Hyun S., Lee G., Kim D., Kim H., Lee S., Nam D., Jeong Y., Kim S., Yeom S., K a ng S., H a n J., L e e B ., H w an g W. (2003 b). Production of nuclear transfer-derived piglets using porcine fetal fibroblasts transfected with the enhanced green fluorescent protein. Biol. Reprod., 69: 1060-1068.

Idziorek T., Estaquier J., De Bels F., A me isen J.C. (1995). YO-PRO-1 permits cytofluorometric analysis of programmed cell death (apoptosis) without interfering with cell viability. J. Immunol. Methods, 185: 249-258.

Im G.S., La i L., L i u Z., Ha o Y., Wax D., B onk A., Prather R.S. (2004). In vitro development of preimplantation porcine nuclear transfer embryos cultured in different media and gas atmospheres. Theriogenology, 61: 1125-1135.

K a p o o r R., R i z vi F., K a k k a r P. (2013). Naringenin prevents high glucose-induced mitochondriamediated apoptosis involving AIF, Endo-G and caspases. Apoptosis, 18: 9-27.

Kawakami M., Tani T., Yabuuchi A., Kobay ashi T., Murakami H., Fujimura T., K a t o Y., Ts u n o d a Y. (2003). Effect of demecolcine and nocodazole on the efficiency of chemically assisted removal of chromosomes and the developmental potential of nuclear transferred porcine oocytes. Cloning Stem Cells, 5: 379-387.

K a w a n o K., K a to Y., Ts u n o d a Y. (2004). Comparison of in vitro development of porcine nuclear-transferred oocytes receiving fetal somatic cells by injection and fusion methods. Cloning Stem Cells, 6: 67-72.

K i m Y.J., A h n K.S., K i m M., S h i m H. (2011). Comparison of potency between histone deacetylase inhibitors trichostatin A and valproic acid on enhancing in vitro development of porcine somatic cell nuclear transfer embryos. In Vitro Cell. Dev. Biol. Anim., 47: 283-289.

Kolber-Simonds D., La i L., Watt S.R., D en aro M., Arn S., A ugenste in M.L., B etthauser J., Carter D.B., Greenstein J.L., Hao Y., Im G.S., Liu Z., Mell G.D., Murphy C.N., Park K.W., Rieke A., Ryan D.J.J., S ach s D.H., Forsberg E.J., Prath e r R.S., H a w l e y R.J. (2004). Production of $\alpha$-1,3-galactosyltransferase null pigs by means of nuclear transfer with fibroblasts bearing loss of heterozygosity mutations. Proc. Natl. Acad. Sci. USA, 101: 7335-7340.

K o o D.-B., K a n g Y.-K., P ark J.S., P ark J.-K., Ch ang W.-K., L e e K.-K., H an Y.-M. (2004). A paucity of structural integrity in cloned porcine blastocysts produced in vitro. Theriogenology, 62: 779-789.

Kues W.A., Anger M., Carnwarth J.W., Paul D., Motlik J., Niemann H. (2000). Cell cycle synchronization of porcine fetal fibroblasts: effects of serum deprivation and reversible cell cycle inhibitors. Biol. Reprod., 62: 412-419.

Kues W.A., Carnwarth J.W., P a 1 D., N i e mann H. (2002). Cell cycle synchronization of porcine fetal fibroblasts by serum deprivation initiates a nonconventional form of apoptosis. Cloning Stem Cells, 4: 231-243.

Kulasekaran P., Scavone C.A., Rogers D.S., Arenberg D.A., Thannickal V.J., Hor ow it z J.C. (2009). Endothelin-1 and transforming growth factor- $\beta 1$ independently induce fibroblast resistance to apoptosis via AKT activation. Am. J. Respir. Cell Mol. Biol., 41: 484-493. 
K u m a r B.M., J in H.F., K i m J.G., O c k S.A., Hong Y., B a l a s ubra m an i a n S., Choe S.Y., R h o G.J. (2007). Differential gene expression patterns in porcine nuclear transfer embryos reconstructed with fetal fibroblasts and mesenchymal stem cells. Dev. Dyn., 236: 435-446.

Kurome M., Fujimura T., Murakami H., Takahagi Y., Wako N., Ochiai T., Miy a z a k i K., N a g a s h i m a H. (2003). Comparison of electro-fusion and intracytoplasmic nuclear injection methods in pig cloning. Cloning Stem Cells, 5: 367-378.

L e e C.K., Piedrahita J.A. (2002). Inhibition of apoptosis in serum starved porcine embryonic fibroblasts. Mol. Reprod. Dev., 62: 106-112.

L e e G.S., K im H.S., Hyun S.H., Kim D.Y., Le e S.H., N a m D.H., J e ong Y.W., Kim S., K a ng S.K., L e e B.C., H w a n g W.S. (2003 a). Improved developmental competence of cloned porcine embryos with different energy supplements and chemical activation. Mol. Reprod. Dev., 66: $17-23$.

Le e G.S., Hyun S.H., Kim H.S., K im D.Y., Lee S.H., Lim J.M., Le e E.S., Kang S.K., L e e B.C., Hw ang W.S. (2003 b). Improvement of a porcine somatic cell nuclear transfer technique by optimizing donor cell and recipient oocyte preparations. Theriogenology, 59: 1949-1957.

L e e J.-W., W u S.-C., T i a n X.C., B a rb e r M., H o a g l a n d T., R i e s e n J., L e e K.-H., Tu C.-F., Cheng W.T.K., Yang X. (2003 c). Production of cloned pigs by whole-cell intracytoplasmic microinjection. Biol. Reprod., 69: 995-1001.

L e e G.S., K im H.S., H y u n S.H., L e e S.H., J e on H.Y., N a m D.H., J e ong Y.W., K im S., K i m J.H., Han J.Y., Ahn C., Kang S.K., L e e B.C., Hwang W.S. (2005). Production of transgenic cloned piglets from genetically transformed fetal fibroblasts selected by green fluorescent protein. Theriogenology, 63: 973-991.

Matthews G.M., N ew b old A., Johnst on e R.W. (2012). Intrinsic and extrinsic apoptotic pathway signaling as determinants of histone deacetylase inhibitor antitumor activity. Adv. Cancer Res., 116: 165-197.

Mohana Kumar B., Jin H.F., Kim J.G., Song H.J., Hong Y., Balasubramanian S., Cho e S.Y., R ho G.J. (2006). DNA methylation levels in porcine fetal fibroblasts induced by an inhibitor of methylation, 5-azacytidine. Cell Tissue Res., 325: 445-454.

Mohana Kumar B., Song H.J., Cho S.K., Balasubramanian S., Choe S.Y., Rho G.J. (2007). Effect of histone acetylation modification with sodium butyrate, a histone deacetylase inhibitor, on cell cycle, apoptosis, ploidy and gene expression in porcine fetal fibroblasts. J. Reprod. Dev., 53: 903-913.

Molgat A.S., Gagnon A., Sorisky A. (2009). Preadipocyte apoptosis is prevented by macrophage-conditioned medium in a PDGF-dependent manner. Am. J. Physiol. Cell Physiol., 296: C757-C765.

Park M.R., Cho S.K., Park J.Y., L e e S.Y., Choi Y.J., Kwon D.N., Son W.J., S e o H.G., K i m J.H. (2004 a). Detection of rare Leydig cell hypoplasia in somatic cell cloned male piglets. Zygote, 12: 305-313.

Park M.R., Cho S.K., Lee S.Y., Choi Y.J., Park J.Y., Kwon D.N., S on W.J., Paik S.S., K i m T., H a n Y.M., K i m J.H. (2004 b). A rare and often unrecognized cerebromeningitis and hemodynamic disorder: a major cause of sudden death in somatic cell cloned piglets. Proteomics, 5: 1928-1939.

Park H.J., K o o O.J., Kw on D.K., Kang J.T., Jang G., L e e B.C. (2010). Effect of roscovitine-treated donor cells on development of porcine cloned embryos. Reprod. Domest. Anim., 45: 1082-1088

S a m i e c M. (2004). Development of pig cloning studies: past, present and future. J. Anim. Feed Sci., 13: $211-238$.

$\mathrm{S}$ a m i e c M. (2005 a). The effect of mitochondrial genome on architectural remodeling and epigenetic reprogramming of donor cell nuclei in mammalian nuclear transfer-derived embryos. J. Anim. Feed Sci., 14: 393-422.

$\mathrm{S}$ a $\mathrm{m}$ i e c M. (2005 b). The role of mitochondrial genome (mtDNA) in somatic and embryo cloning of mammals. J. Anim. Feed Sci., 14: 213-233.

S a mi e c M., S kr zy s z o w s k a M. (2005 a). Microsurgical nuclear transfer by intraooplasmic karyoplast injection as an alternative embryo reconstruction method in somatic cloning of pigs and other mammal species; application value of the method and its technical advantages: a review. Czech J. Anim. Sci., 50: 235-242. 
S a mi e c M., Skrzy szow sk a M. (2005 b). Molecular conditions of the cell nucleus remodelling/ reprogramming process and nuclear-transferred embryo development in the intraooplasmic karyoplast injection technique: a review. Czech J. Anim. Sci., 50: 185-195.

S a miec M., Skrzyszowska M. (2010). The use of different methods of oocyte activation for generation of porcine fibroblast cell nuclear-transferred embryos. Ann. Anim. Sci., 10: 399-411.

S a mi e c M., Skrzyszowska M. (2011). The possibilities of practical application of transgenic mammalian species generated by somatic cell cloning in pharmacology, veterinary medicine and xenotransplantology. Pol. J. Vet. Sci., 14: 329-340.

S a mi ec M., Skrzyszowska M. (2012 a). Roscovitine is a novel agent that can be used for the activation of porcine oocytes reconstructed with adult cutaneous or fetal fibroblast cell nuclei. Theriogenology, 78: 1855-1867.

S a mi e c M., S krzy s z ow sk a M. (2012 b). High developmental capability of porcine cloned embryos following trichostatin A-dependent epigenomic transformation during in vitro maturation of oocytes pre-exposed to $R$-roscovitine. Anim. Sci. Pap. Rep., 30: 383-393.

S a m i e c M., S k r z y s z o w s k a M. (2013). Assessment of in vitro developmental capacity of porcine nuclear-transferred embryos reconstituted with cumulus oophorus cells undergoing vital diagnostics for apoptosis detection. Ann. Anim. Sci., 13: 513-529.

S a mi e c M., Skrzyszowska M., B ochenek M. (2009 a) The use of flow cytometrics for simultaneous measurement of cell cycle and late apoptosis in lipofected porcine foetal fibroblasts before somatic cell cloning. Reprod. Domest. Anim., 44 (Suppl. 3), p. 123.

Samiec M., Skrzyszowska M., Bochenek M. (2009 b). Flow cytometry-mediated detection of late-apoptotic hypodiploid cell fractions in lipofected porcine adult dermal fibroblast cell lines selected for somatic cell nuclear transfer. Reprod. Fertil. Dev., 21, p. 125.

S a mi e c M., Skrzyszowska M., Li i iński D. (2012). Pseudophysiological transcomplementary activation of reconstructed oocytes as a highly efficient method used for producing nucleartransferred pig embryos originating from transgenic foetal fibroblast cells. Pol. J. Vet. Sci., 15: 509-516.

S a mi e c M., Skrzyszow sk a M., O pi e la J. (2013). Creation of cloned pig embryos using contact-inhibited or serum-starved fibroblast cells analysed intra vitam for apoptosis occurrence. Ann. Anim. Sci., 13: 275-293.

S a n t o s F., D e a n W. (2004). Epigenetic reprogramming during early development in mammals. Reproduction, 127: 643-651.

S e r m e u s A., Ge n in M., M a in ce n t A.,Fran solet M., N o t t e A., L e c lere L., R i qui er H., A rn ould T., Michiels C. (2012). Hypoxia-induced modulation of apoptosis and BCL-2 family proteins in different cancer cell types. PLoS One, 7: e47519.

Skrzyszowska M., Karasiewicz J., Bednarczyk M., Samiec M., Smorąg Z., Waś B., Guszkiewicz A., Korwin-Kossakowski M., Górniewska M., Szablis ty E., Modliński J.A.,Łak o ta P.,Wa wrzyńska M., S e chman A.,Wojtys iak D., Hrabia A., Mika M., Li s ow ski M., C zekalski P., Rzą s J., Ka pkowska E. (2006). Generation of cloned and chimeric embryos/offspring using the new methods of animal biotechnology. Reprod. Biol., 6 (Suppl. 1): 119-135.

Skrzyszowsk a M., S a mi e c M., Sło mski R., Li piński D., M ały E. (2008). Development of porcine transgenic nuclear-transferred embryos derived from fibroblast cells transfected by the novel technique of nucleofection or standard lipofection. Theriogenology, 70: 248-259.

Te 1 ford W.G., K in g L.E., F r a k e r P.J. (1992). Comparative evaluation of several DNA binding dyes in the detection of apoptosis associated chromatin degradation by flow cytometry. Cytometry, 13: $137-143$.

Todt F., Cakir Z., Reichenbach F., Youle R.J., Ed li ch F. (2013). The C-terminal helix of Bcl- $x_{L}$ mediates Bax retrotranslocation from the mitochondria. Cell Death Differ., 20: 333-342.

Whitworth K.M., Zh a o J., S p ate L.D., Li R., Prather R.S. (2011). Scriptaid corrects gene expression of a few aberrantly reprogrammed transcripts in nuclear transfer pig blastocyst stage embryos. Cell. Reprogram., 13: 191-204.

Yang J.S., Li u C.W., M a Y.S., Weng S.W., Tang N.Y., Wu S.H., J i B.C., M a C.Y., Ko Y.C., F u n a y a m a S., K u o C.L. (2012). Chlorogenic acid induces apoptotic cell death in U937 leukemia cells through caspase- and mitochondria-dependent pathways. In Vivo, 26: 971-978. 
Yin X.J., Tani T., Yonemura I., Kawakami M., Miyamoto K., Has e gawa R., Ka to Y., Ts u n o d a Y. (2002). Production of cloned pigs from adult somatic cells by chemically assisted removal of maternal chromosomes. Biol. Reprod., 67: 442-446.

Accepted for printing 22 II 2013

\title{
MARCIN SAMIEC, MARIA SKRZYSZOWSKA, MICHAŁ BOCHENEK
}

\author{
Rozwój in vitro klonalnych zarodków świni zrekonstruowanych z jąder komórkowych \\ fibroblastów cytometrycznie analizowanych pod kątem częstotliwości występowania śmierci \\ apoptotycznej i efektywności synchronizacji cyklu mitotycznego w fazach G0/G1
}

\section{STRESZCZENIE}

Celem przeprowadzonych badań było zweryfikowanie, czy metody inhibicji kontaktowej i deprywacji troficznej (głodzenia), zastosowane do sztucznej synchronizacji cyklu mitotycznego komórek fibroblastycznych świni, wpływają w zróżnicowany sposób na rozkład częstości faz cyklu komórkowego i występowanie zjawiska śmierci apoptotycznej w populacjach hodowanych in vitro komórek. Cytometria przepływowa została wykorzystana do analizy cyklu podziałowego komórek somatycznych, które były hodowane w warunkach inhibicji kontaktowej lub głodzenia oraz do równoczesnego wykrywania frakcji późnoapoptotycznych komórek, charakteryzujących się hypodiploidalną liczbą cząsteczek DNA jądrowego. Ponadto, oceniany był przedimplantacyjny rozwój klonalnych zarodków świni, w zależności od użycia różnych metod synchronizacji cyklu mitotycznego dwóch rodzajów komórek-dawców jąder (fibroblastów tkanki skórnej dorosłych osobników i fibroblastów płodowych). Zdolności rozwojowe do osiągnięcia stadium moruli i blastocysty pozostawały na poziomie, odpowiednio: $169 / 278$ (60,8\%) i 76/278 (27,3\%) lub 121/265 (45,7\%) i 46/265 (17,4\%), w odniesieniu do zarodków zrekonstytuowanych $\mathrm{z}$ jąder hodowanych w warunkach inhibicji kontaktowej lub głodzenia fibroblastów tkanki skórnej dorosłych osobników. Z kolei, w następstwie rekonstrukcji enukleowanych oocytów z jąder fibroblastów płodowych, podlegających inhibicji kontaktowej lub głodzonych, odsetek zarodków klonalnych, które rozwinęły się do stadium moruli i blastocysty wynosił odpowiednio: 223/296 $(75,3 \%)$ i 108/296 (36,5\%) lub 165/261 (63,2\%) i 67/261 (25,7\%). Podsumowując, analiza cytometryczna hodowanych komórek fibroblastycznych świni (fibroblastów tkanki skórnej dorosłych osobników oraz fibroblastów płodowych) wykazała wysoką skuteczność synchronizacji ich cyklu mitotycznego w stadiach G0/G1, zarówno w wyniku inhibicji kontaktowej, jak i głodzenia. W przypadku obu rodzajów fibroblastów wykorzystanych do rekonstrukcji enukleowanych oocytów, metody synchronizacji cyklu podziałowego komórek-dawców jąder wywierały znaczący wpływ na potencjał rozwojowy in vitro klonalnych zarodków świni. Zarodki zrekonstruowane z jąder komórkowych fibroblastów płodowych, hodowanych w warunkach inhibicji kontaktowej lub deprywacji troficznej, charakteryzowały się istotnie wyższymi kompetencjami rozwojowymi do osiągnięcia stadiów moruli/blastocysty niż zarodki zrekonstruowane $\mathrm{z}$ jąder poddanych inhibicji kontaktowej lub głodzeniu fibroblastów tkanki skórnej dorosłych osobników. 